\title{
Analytical Study about the Effects of Social Media on Social Interactions of Students of Age Limits 14 - 21 Years
}

\author{
${ }^{a}$ Mubashrah Jamil, ${ }^{\mathrm{b}}$ Shaziah Jamil, ${ }^{\mathrm{c}}$ Allay Hayder Urooj \\ ${ }^{a}$ Assistant Professor, Department of Education, Bahauddin Zakariya University, Multan, Pakistan \\ Email: mubashrahjamil@bzu.edu.pk \\ ${ }^{\mathrm{b}}$ Assistant Professor, Department of Education, The Women University, Multan, Pakistan \\ ${ }^{\mathrm{c}}$ Broadcasting Manger, Director of Outreach, University of Agriculture, Faisalabad, Pakistan
}

\begin{tabular}{|c|c|}
\hline ARTICLE DETAILS & ABSTRACT \\
\hline $\begin{array}{l}\text { History: } \\
\text { Accepted o8 April } 2021 \\
\text { Available Online June } 2021\end{array}$ & \multirow{5}{*}{$\begin{array}{l}\text { Basic purpose of this research was to explore the emerging effects of } \\
\text { social media on students' social interactions. For this purpose a sample } \\
\text { of } 380 \text { students was selected on the basis of purposive sampling } \\
\text { technique during the academic year 2019. Through a self-developed } \\
\text { questionnaire, researchers collected data from different elementary to } \\
\text { higher secondary schools' students and also the undergraduate students } \\
\text { of semester first from the universities that were present on the day of } \\
\text { data collection in their classes. It was found that WhatsApp, YouTube, } \\
\text { FaceBook, Google+, and Instagram were the most popular websites or } \\
\text { apps amongst the sampled students and they spent more than } 4 \text { hours in } \\
\text { a day on different social media activities. Getting entertainment through } \\
\text { these apps or websites was the basic purpose of using it. Social media } \\
\text { has strong impacts on the social interactions of both male and female } \\
\text { students because they feel their lives are incomplete without using it and } \\
\text { they don't like those who criticize on them while using it but students of } \\
\text { early ages i.e., } 14 \text { - } 17 \text { years were least affected by it. } \\
\text { (C) } 2021 \text { The authors. Published by SPCRD Global Publishing. This is an } \\
\text { open access article under the Creative Commons Attribution- } \\
\text { NonCommercial } 4.0\end{array}$} \\
\hline $\begin{array}{l}\text { Keyw } \\
\text { Socia } \\
\text { Socia } \\
\text { ICTs }\end{array}$ & \\
\hline $\begin{array}{l}\text { JEL Classifica } \\
L 82,017\end{array}$ & \\
\hline DOI: $10.47067 /$ real.v4i2.142 & \\
\hline & \\
\hline
\end{tabular}

Corresponding author's email address: mubashrahjamil@bzu.edu.pk

\section{Introduction}

Humans are known as social animals and they live together as a part of society. Throughout our lives, we learn to interact with others to build social interactions. These social interactions have significant impact on our lives. For example; through social interaction, we communicate our life experiences, we learn from others' life experiences, we can communicate our feelings and likings and also dis-likings, we can explore other's life styles and cultural differences, businesses establish and promoted through these social interactions and the most important is that in an educational institute learning environment launches teaching-learning process through these social interactions either between teachers-students, teachers-teachers, administration-teachers-students, students-students and in short between all educational stack holders and the society. By adding to this, Okita (2016) said: 
'underneath the broad umbrella of social interactions and learning variants can range from peer learning, reciprocal teaching, learning by teaching, learning by observation, learning by doing, and self-other monitoring'. Hurst, Wallace and Nixon (2013) quoted from Routman as: 'students learn more when they are able to talk one another and be actively involved'.

Technological developments have changed the way and even replaced the methods of social interactions. These technological developments can be educationally beneficial to teachers and students in supporting the sharing of resources, enhancing motivation, facilitating in reflection, social interaction and knowledge building (Lu, Churchill, 2012). Related to this, Bozkurt, Karadeniz, Kockdar and Kocdar (2017) expressed that 'social networking technologies, offering appealing communication tools for daily life and e-learning environments, allowing students to form digital identities and express themselves digitally'. Karadeniz et al., further expressed that in 2016 total world population was 7.395B. Out of this, 3.419B were Internet users and 2.307B were active social media users. Twitter, Facebook, blogs and Instagram are considered as social media sites (Wolf, Sims \& Yang, 2018). Manning (2014) expressed that social media involves interaction that might include family, friends or acquaintances or with new people who share common interests.

Social media is computer mediated technology facilitating the sharing of ideas, social awareness, career interests, exchange of knowledge and other methods of expression through social networks and virtual communities (Abbas, Aman, Nurunnabi, and Bano 2019). On the other hand Julian (2017) declared that, "Social media are Internet-based channels that allow users to opportunistically interact and selectively self-present, either in real-time or asynchronously, with both broad and narrow audiences who derive value from user-generated content and the perception of interaction with others". According to this definition, social network sites (e.g., Facebook, QQ, Google+, YouTube, Yelp, and Pheed); professional network sites like LinkedIn; chat boards and discussion forums, social games; Wiki Talk; Tinder; Instagram; Yik Yak are included in social media sources but online news channels, Wikipedia, Skype, Netflix, Email, SMS/Texts, Tumblr and Whisper are not.

Social media has positive and/or negative both impacts and also it varies from person to person means of using the same. Having smart phones to both teachers and students is not a secret today. From the literature, it was derived by different researchers about the impacts and effects of social media on students' learning behaviors. For example, sharing of lecture, notes, submission of online assignments, research problems, online admissions, applying for jobs, attending online seminars and conferences, learning at their own pace, and academic counseling (Pojazon-Zazik \& Park, 2010; Raut \& Patil, 2016; Siddiqui and Singh, 2016; Gok, 2016; Lad, 2017; Ghore, 2019) are the positive effects of social media in students' learning behaviors. While spending more time on social media instead of doing their homework, studying the courses, preparation or examinations, and losing their grades and GPAs (Owusu-Acheaw and Larson, 2015; Mensah and Nizam, 2016; Abbas, Aman, Nurunnabi and Bano, 2019) are the derived negative impacts of social media. Not only this, due to the availability of unlimited, unwanted, irrelevant, uncensored videos and reading stuff on social media resulted in missing the innocence in young age and the cases of cyber bullying are increasing in educational day by day (Pojazon-Zazik \& Park, 2010; O’Keeffe, et al., 2011; Amedie, 2015). Health-wise issues among the students were reported as loss of memories, depression, anxiety, backbone problem, and loss of eye site are common (Strickland, 2014; Gok, 2016; Lad, 2017).

Umar and Idris (2018) conducted a study on 306 students to measure the effects of social media on their education and social behaviors. They found that students spending most of their time on social media, resulted in paying less attention to other responsibilities and hence lead to negative outcomes. 
But social media also helps them to become more social among their peers and family and improved connectivity among the same. But it also gives rise to cyber bullying, glamorizes drug abuse and can sometimes make students unhappy, fear of missing out, and lastly it leads to restlessness. Umar \& Idris continues to declare that students at school level are under the pressure to be perfect, to look perfect, act perfect, to have the perfect group of friends, the perfect amount of likes and followership, and the rest. Failure for the students to meet the ridiculous levels, results in serious backwardness both academically and psychologically. Regarding the social media and students' social behaviors - few evidences were found from the literature. It was attractive for the researchers to explore more about the topic at their region where this type of studies are still ignored by the researchers. Therefore, the main objective of this research was to identify the current practices and the effects of social media on the academic performance and social behavior of those students which were lying between the age group of 14 - 21 years old and were currently enrolled at elementary to higher secondary school levels.

\section{Research Questions}

To conclude the research, following research questions were drawn:

1. Whether all students possess their own cell phones?

2. Which types of social media apps and/or web sites are more popular amongst the samples students?

3. For what time limits and purposes do the sampled students use the social media web sites and/or apps?

4. Whether social media is highly influenced on early age group students' social behaviors?

5. Whether continuous engagement in social media affects differently on male and female students' social behaviors?

\section{Test Hypotheses}

To test whether social media affect sampled students gender-wise or age-wise, following hypotheses were constituted and were tested through $\chi^{2}$ test statistics:

\begin{tabular}{|l|l|}
\hline Gender Based Hypothesis & Age Based Hypothesis \\
\hline $\begin{array}{c}\text { Ho: Females are highly influenced though Social } \\
\text { media. }\end{array}$ & $\begin{array}{r}\text { Ho: Senior age group students (i.e., 18-21 } \\
\text { years) were highly influenced by the social } \\
\text { media. }\end{array}$ \\
\hline H1: Social media affect both genders equally. & $\begin{array}{l}\text { H1: Junior age group students (i.e., 14-17 years) } \\
\text { were highly influenced by the social media. }\end{array}$ \\
\hline
\end{tabular}

The $\chi^{2}$ test at $\mathrm{df}=1$ (for gender based hypothesis) and $\mathrm{df}=3$ (for age based hypothesis) at $\mathrm{p}=0.05$ was used to verify the above hypotheses.

\section{Methods}

The present study used survey based research design. According to Gay, Mills \& Airasian (2015), "survey research involves collecting data to test hypotheses or to answer questions about people's opinions on some topic". A self-developed questionnaire was constructed by the researchers to collect the required data. The questionnaire was designed according to the set objectives of this article. The questionnaire was comprised of three sections. First section was related to the basic information about students i.e., their gender, class, ownership of cell phone, type of social media web sites being used by them, time spend by them and purposes of using the social media was asked. Second section contained 12 statements. These statements were drawn through review literature and were related to social 
media's effect on their social activities. They were asked to respond in Yes/No format i.e., if the given statement suits or match to their personal experiences or not. The third section was comprised of two open ended questions i.e., one of the questions was about the uses of social media by themselves and second one was about their perceived effect of social media on their personal lives. To measure the reliability of this questionnaire pilot study was conducted and existing senior educationists and research experts available in the public sector universities (Bahauddin Zakariya University, Multan, University of Education, Lahore (Multan Campus) and University of Agriculture, Faisalabad) were consulted to measure its face validity. Total 15 students ( 6 male and 9 females) were involved in the pilot study. After pilot study some statements of the questionnaire were required to re-structure because they were difficult for them to understand and format of the questionnaire was reconsidered as per identified and asked by the students. While, the educationists and senior experts (after piloting the questionnaire) - consulted for its face validity - approved it collectively.

Purposive sampling technique was used to collect the required data. The targeted population of this research was those students whose age limits were between $14-21$ years. Students of this age limits were studying in different educational levels i.e., from elementary to higher secondary schools during the academic year 2019. So, it was a good opportunity for the researchers to analyze the impacts of social media in different dimensions i.e., gender-wise, age-wise and education-wise (in this research paper only one factor was tested). To secure the time and other resources, total 3 secondary and 2 higher secondary government schools of Multan city were delimited for this purpose. Ethically, prior permission for data collection was taken from the heads of these schools. Researchers collected data by themselves from the students available in their classrooms on the day of data collection. Therefore, the return rate of the questionnaires was maximum i.e., 98\%. Demographically distribution of the sampled students is given as under:

\section{Table 1: Demographic Information of the Sampled Students}

\begin{tabular}{|l|l|l|}
\hline Sample (Category) & $\mathbf{N}$ & $\%$ \\
\hline Gender: & 193.00 & $51 \%$ \\
\hline Male & 187.00 & $49 \%$ \\
\hline Female & \multicolumn{2}{|l|}{} \\
\hline Age Groups (years): & 90.00 & $23.68 \%$ \\
\hline $14-15$ years & 100.00 & $26.32 \%$ \\
\hline $16-17$ years & 100.00 & $26.32 \%$ \\
\hline $18-19$ years & 90.00 & $23.68 \%$ \\
\hline $20-21$ years & & \\
\hline
\end{tabular}

\section{Results and Discussion}

From Table 2, it was found that total $65 \%$ sampled students were having cell phones. Out of this range $80 \%$ males possessed their own cellular phones while 91\% students of age category $20-21$ years claimed for having their own cell phones. Out of 380 sampled students, 35\% disclosed that they do not have their own cell phones. From the range of these students, 43\% students were using their Mother's cell phones. 
Table 2: $\quad$ Possession of the Cell Phone or Used by - (others)

\begin{tabular}{|l|c|c|}
\hline Category & F & \% \\
\hline Total Sample & 246.00 & 65.00 \\
\hline Male & 154.00 & 80.00 \\
\hline Female & 92.00 & 49.00 \\
\hline $14-15$ years & 30.00 & 33.00 \\
\hline $16-17$ years & 53.00 & 53.00 \\
\hline $18-19$ years & 82.00 & 91.00 \\
\hline $20-21$ years & 82.00 & 43.00 \\
\hline Used by (In case of having NO cell phone) & 28.00 \\
\hline Mother & 58.00 & 08.00 \\
\hline Father & 38.00 & 11.00 \\
\hline Sister & 11.00 & 07.00 \\
\hline Brother & 15.00 & \\
\hline Friend & 10.00 & \\
\hline
\end{tabular}

Table 3 is showing percentages of the sampled students' responses about the types of social media. It was depicted from this table that WhatsApp (WA), YouTube (YT), Face Book (FB), Google+ (G+), Instagram (IG) and Twitter (321, 254, 237, 169, 123 and 51 - calculated frequencies respectively) were the most popular social media apps or websites in sequence among the sampled students. Total $89 \%$ females were found more frequent user of WhatsApp while male were leading in all other types i.e., $69 \%$ of YT, $68 \%$ of $\mathrm{FB}$ and $49 \%$ of G+ respectively. It was alarming to know that $95 \%$ students of age group 20-21 years and 89\% of 14-15 years students were the most frequent users of WA while rest of the all results of all other types of social media showed that the oldest age group was taking lead and then 16-17years of students were following them. Overall very few or none of the students' percentages were found in using LinkedIn, Tumbler, Pinterest and Twitter respectively. While few of the sampled students' expressed that they were using TikTok (04\%), SanpChat (02\%), VideMate (02\%) and PubG (1\%). Where TikTok and Snapchat are video based apps and VideMate is an internet website which facilitates in downloading online videos.

Table 3: $\quad$ Types of Social Media used by the Sampled Students

\begin{tabular}{|l|l|l|l|l|l|l|l|l|l|}
\hline Category & FB & Twitter & $\mathbf{I G}^{1}$ & $\mathbf{W A}^{2}$ & $\mathbf{L I}^{3}$ & $\mathbf{Y T}^{4}$ & $\mathbf{P}^{5}$ & $\mathbf{T}^{6}$ & $\mathbf{G}^{7}$ \\
\hline Total Sample & $62 \%$ & $13 \%$ & $32 \%$ & $85 \%$ & 03\% & $67 \%$ & $10 \%$ & 03\% & $44 \%$ \\
\hline Male & $68 \%$ & $18 \%$ & $35 \%$ & $80 \%$ & $04 \%$ & $69 \%$ & $12 \%$ & $05 \%$ & $49 \%$ \\
\hline Female & $56 \%$ & $19 \%$ & $29 \%$ & $89 \%$ & 02\% & $64 \%$ & 08\% & 01\% & $40 \%$ \\
\hline $14-15$ years & $60 \%$ & $07 \%$ & $23 \%$ & $89 \%$ & None & $64 \%$ & $07 \%$ & None & $44 \%$ \\
\hline $16-17$ years & $67 \%$ & $07 \%$ & $17 \%$ & $78 \%$ & None & $63 \%$ & 03\% & 01\% & $43 \%$ \\
\hline $18-19$ years & $53 \%$ & $19 \%$ & $42 \%$ & $82 \%$ & 04\% & $66 \%$ & $19 \%$ & 09\% & $44 \%$ \\
\hline $20-21$ years & $70 \%$ & $20 \%$ & $48 \%$ & $95 \%$ & $10 \%$ & $73 \%$ & $11 \%$ & 03\% & $47 \%$ \\
\hline
\end{tabular}

IG=Instagram; $\quad$ WA=WhatsApp $\quad$ LI=LinkedIn; $\quad$ YT=YouTube; $\quad \mathbf{P}=$ =Pinterest; $\quad$ T=Tumbler; G+=Google+

Table 4 is showing the calculated percentages of the responses of the sampled students 
regarding the time spent by them in utilizing social media apps or websites. Maximum 31\% ( $n=117)$ disclosed that spent their time on social media for 90 minutes in all. Next highest percentage disclosed for using internet for 30 minutes in all $(23 \%, n=90)$, more than $19 \%$ expressed that they use social media for 4 hours and sometimes more that than 4 hours in a day $(19 \%, n=72)$ and $13 \%$ each for $1-4$ hours users $(n=49)$. Sampled male students' response rate were quite alarming i.e., $23 \%$ were using for more than 4 hours while sampled female students' responses were also quite astonishing i.e., 32\% of them were using for just less than or equal to 30 minutes. Total $42 \%$ students of age group 14-15 years were involved for less than or equal to 30 minutes; $38 \%$ of $16-17$ years for maximum 60 minutes, $26 \%$ of students 18-19 years for more than 4 hours and 31\% of age group of 20-21 years students were spending their time for more than 4 hours respectively. Baker (2019) expressed in her study that there is no significant correlation between the social media use and depression or anxiety; but a strong correlation exists between the times spent on using social media.

Table 4: $\quad$ Time Spent on Social by the Sampled Students (in a day)

\begin{tabular}{|l|l|l|l|l|l|}
\hline Category & $\mathbf{>} \mathbf{3 0}$ mins & $\mathbf{3 0} \mathbf{m i n}-\mathbf{1} \mathbf{h r}$ & $\mathbf{1}-\mathbf{3} \mathbf{h r s}$ & $\mathbf{2}-\mathbf{4} \mathbf{h r s}$ & $<\mathbf{4}$ hrs \\
\hline Total Sample & $\mathbf{2 3} \%$ & $31 \%$ & $13 \%$ & $13 \%$ & $19 \%$ \\
\hline Male & $16 \%$ & $31 \%$ & $15 \%$ & $15 \%$ & $23 \%$ \\
\hline Female & $32 \%$ & $31 \%$ & $11 \%$ & $11 \%$ & $15 \%$ \\
\hline $14-15$ years & $42 \%$ & $36 \%$ & $07 \%$ & $13 \%$ & $02 \%$ \\
\hline $16-17$ years & $31 \%$ & $38 \%$ & $10 \%$ & $05 \%$ & $16 \%$ \\
\hline $18-19$ years & $13 \%$ & $26 \%$ & $15 \%$ & $20 \%$ & $26 \%$ \\
\hline $20-21$ years & $09 \%$ & $23 \%$ & $23 \%$ & $13 \%$ & $31 \%$ \\
\hline
\end{tabular}

Table 5 showed purposes of using social media by the sampled students. It was found that students from all demographic categories used social media for entertainment i.e., ranges fall from 50\% - 52\%. Next highest percentage showed that they use social media to stay in touch with their friends and family members residing within or out of the city and/or country. Third highest purpose of using social media was to collect and share information between and/or from friends, family and or national or international level i.e., the percentages from all categories found from 31\% - 50\%. Same as students from all categories were unable to understand how to get familiar or become popular through social media i.e., the percentages were ranged from $08 \%-19 \%$. But $40 \%$ of the students from age category 20-21 years expressed that they use social media to kill their spare time.

Table 5: $\quad$ Purposes of Using Social Media - Sampled Students' Responses

\begin{tabular}{|l|l|l|l|l|l|l|l|}
\hline Category & Total & Male & Female & $\mathbf{1 4 - 1 5}$ yr & $\mathbf{1 6 - 1 7} \mathbf{~ y r}$ & $\mathbf{1 8 - 1 9}$ yr & $\mathbf{2 0 - 2 1}$ yr \\
\hline For friendship & $\mathbf{2 1} \%$ & $24 \%$ & $17 \%$ & $\mathbf{2 7} \%$ & $\mathbf{2 0} \%$ & $\mathbf{1 8} \%$ & $19 \%$ \\
\hline Stay in touch & $43 \%$ & $44 \%$ & $42 \%$ & $44 \%$ & $46 \%$ & $46 \%$ & $36 \%$ \\
\hline Entertainment & $51 \%$ & $52 \%$ & $50 \%$ & $49 \%$ & $51 \%$ & $51 \%$ & $52 \%$ \\
\hline Information & $40 \%$ & $38 \%$ & $42 \%$ & $29 \%$ & $31 \%$ & $50 \%$ & $40 \%$ \\
\hline Popularity & $13 \%$ & $14 \%$ & $11 \%$ & $08 \%$ & $11 \%$ & $12 \%$ & $19 \%$ \\
\hline Interest & $23 \%$ & $23 \%$ & $23 \%$ & $29 \%$ & $17 \%$ & $27 \%$ & $19 \%$ \\
\hline Audio-Video & $23 \%$ & $28 \%$ & $18 \%$ & $31 \%$ & $10 \%$ & $26 \%$ & $27 \%$ \\
\hline Kill the time & $24 \%$ & $23 \%$ & $26 \%$ & $17 \%$ & $10 \%$ & $31 \%$ & $40 \%$ \\
\hline
\end{tabular}


Table 6 displayed responses of the students regarding their experiences about social media's effect on their social life or behaviors. This table reflected the percentages of only those responses which they marked for "Yes" means 'agreement with the given statement'. Total twelve (12) statements were given to the respondents and were required to mark on either "Yes" or "No". Statement-wise results of these statements were as under:

Statement1: Do you feel your social life is disturbed due to more time spent on internet/cellular based activities? In the response of this question, a good majority of overall sampled students and other categories except the senior age group students (i.e., 20-21 years old) accepted that their social life was disturbed due to continuous engagement on internet based activities. No significant differences were found between the results of gender-based comparison. While comparing the sampled students' w.r.t. their age groups, percentages showed that senior age group students were less affected by social media activities. But $\chi^{2}$ test $\left(\chi^{2}=0.9432, \mathrm{df}=3, \mathrm{p}=0.05\right)$ declared that there is no significant differences found between the results of all age group values.

Statement2: Do you keep your mobile data in use while traveling with your family? Simple majority of the sampled students accepted the statement. No significant differences between the results of male and female students found. Same as no significant differences found between the calculated percentages of age-wise comparison. But the results of $\chi^{2}$ tests revealed that $\left(\chi^{2}=19.5154, \mathrm{df}=3, \mathrm{p}=0.05\right)$ the null hypothesis is accepted because the calculated value of $\chi^{2}$ tests is greater than the tabulated value i.e., 7.815 at $95 \%$ level of significance.

Statement3: Do you feel you are losing your friends due to long time spent on social media activities? A good majority of overall sampled students denied with the given statement. They believe they have more friends and they are more socially active than before. Calculated percentages of female students were lower than to the male students. It means female students have wider friendship circle on social media as compared to males. We accept null hypothesis in this case because the calculated values of $\chi^{2}$ tests $\left(\chi^{2}=3.1082, \mathrm{df}=1 ; \mathrm{p}=0.05\right)$ was nearest to the tabulated value i.e., 3.841. While comparing the sampled students' w.r.t. their age groups, youngest students were strictly denied the statement and they believe they have more friends through social networking than before. It was confirmed when hypothesis was tested because the calculated value of $\chi^{2}$ test $\left(\chi^{2}=74.874, \mathrm{df}=3, \mathrm{p}=0.05\right)$ was quite higher than that of tabulated value i.e., 7.815 at $95 \%$ level of significance. Therefore, null hypothesis was accepted.

Statement4: Do you treat harshly those who interrupt you while you are involved in social media activities? The calculated percentages of the responses showed that the sampled students moderately accepted the statement. When gender-based comparison was made, it was found that the calculated value of $\chi^{2}$ test $\left(\chi^{2}=0.0544, \mathrm{df}=1, \mathrm{p}=0.05\right)$ was lower than that of tabulated value i.e., 3.841; therefore, alternative hypothesis was accepted. In case of age wise comparison, variations found between the calculated values of percentages. For example, good majority of students of age group 18-19 years accepted the statement (i.e., 65\%); then next highest percentage was of senior most category of the students (i.e., 56\%) and the lowest calculated percentage was of 16-17 years students (i.e., 45\%). Due to this variation, the calculated value of $\chi^{2}$ test $\left(\chi^{2}=33.2665, \mathrm{df}=3, \mathrm{p}=0.05\right)$ was higher than that of tabulated value. Therefore, we accepted null hypothesis in this situation.

Statement5: Do you feel scared when someone unknown starts unhealthy communication on net? The calculated percentages of the responses of sampled students for this statement were quite lower 
i.e., it ranged $28 \%$ to $48 \%$. Overall, sampled students were not scared of this type of unhealthy activity. When we recall the results of Table 5, we already found that maximum students' used social media for entertainment. Therefore, the results of this statement also verified through this source. Social media does not necessarily help people make new friends, but only help to strengthen, build, and maintain friendships and already existing relationships.

Statement6: Do you feel loneliness at home or in family due to more time spent in social media? The response rate in the favor of this statement was also very low. Means, they never feel loneliness at home or in family because they remain busy and engaged in social media based activities they have many friends and lot of entertainment through internet and social media apps. This results was totally opposite to the findings of Amedie (2015) which disclosed that excessive use of social media can create depression may be at risk of social isolation and sometimes turn to risky Internet sites and blogs for help that may promote substance abuse, unsafe sexual practices, aggressive and self-destructive behaviors.

Statement7: Do you get annoyed when people start criticizing you on social media? A very good majority of overall sampled students and the students from different categories accepted that they don't like to be criticized by anyone on the social media. People usually post some messages on social media, i.e., FB and Instagram and others give comments regarding the post. Some likes it and others not. So, the unlikeness was not accepted by the sampled students. Through the calculated percentages of male and female responses we can say that both categories accepted the situation but we cannot make decision whether female are more annoyed or male. The test statistics also rejected the null hypothesis for gender based comparison because the calculated value of $\chi^{2}$ test $\left(\chi^{2}=0.0357, \mathrm{df}=1, \mathrm{p}=0.05\right)$ was very low than that of tabulated value. In case of age group wise comparison, it was found that percentages of senior age group students were higher. And this was verified by the calculated value of $\chi^{2}$ test $\left(\chi^{2}=2.4011, d f=3, p=0.05\right)$. So, null hypothesis was rejected in this case as well.

Statement8: Do you feel jealousy from those known persons whose posts are liked more on social media than that of yours? A very good majority also accepted the situation openly. They were agreed that they got jealous when some known persons' posts are more liked by the audience on social media. Although the difference between the calculated percentages exists between both group comparison i.e., gender based and age group comparisons. Male students' percentage and senior age groups' students' percentages were higher. But these differences were minor and not significantly acceptable. We accepted the alternate hypotheses in both types of comparisons because he calculated values of $\chi^{2}$ tests for both categories were lower than that of tabulated values, i.e., for gender based comparison $\left(\chi^{2}=0.7706, d f=1, p=0.05\right)$ and for age group wise comparison $\left(\chi^{2}=1.7973, d f=3, p=0.05\right)$.

Statement9: Do the news or rumors on social media made you conscious in your routine life? A good majority of students accepted the situation and expressed that psychologically they become conscious when they found any news on social media. This consciousness is not negative in all cases; for example, they become conscious when they found upcoming or emerging trends of fashion, hair styles, shoes, makeup and so on. And yes they also become conscious and search more curiously when they hear any dangerous news through social media; for example, COVID19 virus news. The null hypothesis was rejected in case of gender based comparison i.e., $\left(\chi^{2}=1.7980, d f=1, p=0.05\right)$ and accepted in case of age groups comparison $\left(\chi^{2}=12.0508, \mathrm{df}=3, \mathrm{p}=0.05\right)$ because of the variations exists between the calculated percentages of both categories.

Statement10: Do you feel you are losing trust on people or on your friends? Overall a very good 
majority of the sampled students accepted the situation and expressed that they normally don't believe on people around them in real life as well because they deal and/or face many fake news, fake IDs and IT-based magnified pictures and videos in routine on social media. Responses of male and female were same but some variation was found amongst the age groups but these variations are not significantly different and acceptable. Null hypotheses were therefore rejected for both categories because the calculates values of $\chi^{2}$ test were lower than that of tabulated values i.e., for gender based comparison $\left(\chi^{2}=0.4805, \mathrm{df}=1, \mathrm{p}=0.05\right)$ and for age group wise comparison $\left(\chi^{2}=0.6446, \mathrm{df}=3, \mathrm{p}=0.05\right)$.

Statement11: Do social media helped you in making your personality more perfect than before? Again, a very good majority of the sampled students accepted that their personality become more perfect and they feel pleasure by expressing that they wear and act as per the 'demand of time'. As proven by the Umar and Idris (2018) that the usage of social media has evolved trending issues among the senior secondary school students. Percentages of male students and senior age group students were higher. But the null hypotheses were rejected for both type of comparison because of lower calculated values of $\chi^{2}$ test i.e., for gender based $\left(\chi^{2}=2.0589, \mathrm{df}=1, \mathrm{p}=0.05\right)$ and for age - wise comparison $\chi^{2}$ $\left(\chi^{2}=0.5841, \mathrm{df}=3, \mathrm{p}=0.05\right)$. The reason of rejection was the higher calculated percentages of response rates from all type of categories; therefore, it was comparatively difficult to declare either male were more satisfied with the given statement or female and so on.

Statement12: Do you believe life is incomplete without social media? The response rate showed that sampled students' moderately accepted the situation. A significant difference was found between the responses of senior age group students and junior ones. Senior age group students were found more tagged with social media as compared to juniors. Null hypothesis was rejected in case of gender based comparison and accepted in case of age-groups comparison i.e., $\left(\chi^{2}=0.5484, \mathrm{df}=1, \mathrm{p}=0.05\right)$ and $\left(\chi^{2}=34.3275, \mathrm{df}=3, \mathrm{p}=0.05\right)$ respectively.

At the end Pearson Product Moment Correlation (r) was calculated to find the effects of social media on social b55ehaviors of male and female students and between the age groups of the sampled students. The calculated values for correlation were $\mathrm{r} 1=0.9638 ; \mathrm{r} 2=0.8011$ and $\mathrm{r} 3=7830$ (i.e., $\mathrm{r} 1$ for gender based comparison; r2 for junior age group students and r3 for senior age group students respectively). From these values it was found that all categories of sampled students were positively influenced by social media activities; but male and female and junior age group students are comparatively highly influenced than that of senior age group students. 
Table 6: $\quad$ Effects of Social Media on Social Behavior - Sampled Students' Responses (Only "Yes")

\begin{tabular}{|l|l|l|l|l|l|l|l|}
\hline Statements & Total & Male & Female & $\mathbf{1 4 - 1 5}$ yr & $\mathbf{1 6 - 1 7}$ yr & $\mathbf{1 8 - 1 9}$ yr & $\mathbf{2 0 - 2 1}$ yr \\
\hline Statement 1 & $68 \%$ & $67 \%$ & $68 \%$ & $69 \%$ & $76 \%$ & $72 \%$ & $52 \%$ \\
\hline Statement 2 & $58 \%$ & $58 \%$ & $59 \%$ & $57 \%$ & $53 \%$ & $64 \%$ & $60 \%$ \\
\hline Statement 3 & $47 \%$ & $52 \%$ & $43 \%$ & $31 \%$ & $55 \%$ & $48 \%$ & $54 \%$ \\
\hline Statement 4 & $54 \%$ & $55 \%$ & $54 \%$ & $52 \%$ & $45 \%$ & $65 \%$ & $56 \%$ \\
\hline Statement 5 & $35 \%$ & $37 \%$ & $32 \%$ & $32 \%$ & $28 \%$ & $32 \%$ & $48 \%$ \\
\hline Statement 6 & $40 \%$ & $45 \%$ & $35 \%$ & $36 \%$ & $39 \%$ & $36 \%$ & $51 \%$ \\
\hline Statement 7 & $73 \%$ & $73 \%$ & $72 \%$ & $57 \%$ & $62 \%$ & $87 \%$ & $84 \%$ \\
\hline Statement 8 & $72 \%$ & $74 \%$ & $70 \%$ & $70 \%$ & $66 \%$ & $78 \%$ & $74 \%$ \\
\hline Statement 9 & $61 \%$ & $64 \%$ & $57 \%$ & $63 \%$ & $59 \%$ & $63 \%$ & $58 \%$ \\
\hline Statement 10 & $68 \%$ & $69 \%$ & $69 \%$ & $61 \%$ & $73 \%$ & $64 \%$ & $74 \%$ \\
\hline Statement 11 & $70 \%$ & $74 \%$ & $69 \%$ & $61 \%$ & $68 \%$ & $77 \%$ & $74 \%$ \\
\hline Statement 12 & $54 \%$ & $56 \%$ & $52 \%$ & $46 \%$ & $43 \%$ & $65 \%$ & $64 \%$ \\
\hline
\end{tabular}

\section{Discussion}

The following outcomes were derived on the bases of above calculated results and stated research questions in early section of this study.

Question 1: Whether all students possess their own cell phones? Overall a good majority of the sampled students possessed their own cell phones. Male students and senior age group students were more empowered than others in this case. Others who don't have their own - were using of their mother's cell phone for this purpose.

Question 2: Which types of social media apps and/or web sites are more popular amongst the samples students? It is concluded that WhatsApp, YouTube, Face Book, Google+, Instagram and Twitter are the most popular social media websites and/or apps in sequence amongst the samples students. While some of the sampled students were using TikTok, PubG and Pinterest.

Question 3: For what time limits and purposes do the sampled students use the social media web sites and/or apps? Time limits were varying among the different categories of sampled students. Maximum sampled students were involved in social media activities for 90 minutes overall; male students and students of senior most age group i.e., 20-21 years expressed that they use social media for 4 and some times more than 4 hours in a day.

Majority of the sampled students use social media for entertainment; female used it for collecting information, killing the spare time and stay in touch with family and friends via social media; male students were interested in making friends and downloading videos from the internet; junior age group students used social media for making friends, keep in touch with family and friends and downloading videos from internet while majority of the senior age group students use social media to kill the spare time, and downloading information from the internet.

Question 4: Whether social media is highly influenced on early age group students' social behaviors? No, it wasn't proved in this study. If we analyze in sequence then we conclude that majority 
of the junior age groups students' don't have their own cell phones, they use internet for limited time period as compared to senior age group students. And the calculated results of overall data also reflect that juniors response rate were lowered that that of senior age group students. Means senior age group students were more socially influenced by the social media activities. For example; they feel social media has made their personality more perfect and life is incomplete without social media; they like keep using social even if they were traveling with family, they don't like those people who criticize them on social media and they don't like interruptions while using mobile phone. While in some situations junior age group students' were quite excited regarding the utilization of social media. For example; they feel they have more friends around the world and they become more disturbed or conscious when they hear any news or rumor on social media. In any situation, it is concluded that social behaviors of all age groups are affected by the social media but juniors age group students are even more influenced than that of seniors.

Question 5: Whether continuous engagement in social media affects differently on male and female students' social behaviors? In this research this hypothesis was also rejected. In the given statements the responses of male and female students were almost similar. Therefore, we can't say that either male are more affected than that of female or vice versa. The highly correlated values also reflect that both male and female students were equally affected socially through the social media activities.

\section{Conclusion}

From the above discussion, it was concluded that almost all the students of age 16 and above possess their own cell phones and keep using it for long time either during their studies and/or spare times. Male were one step ahead in this case as compared to females. It was concluded from all-over the results that social media is the main source of their entertainment and they never hesitated for using either sitting with their family members or traveling around and/or outside the city or in any other situation. Social media is now their stronger companion and they like to spare their free time on it rather than with their families, friends or going for any other physical activity. They accepted that their social life has been badly affected due to spending more time on social media but they believe they can keep in-touch with their friends and family members through social media more frequently and were satisfied on this type of interaction. They don't like those who criticize them for continuous using of their cell phones. They never feel loneliness or are scared from any unhealthy activity on social media. They feel jealous from those whose posts are being more liked by the people as compared to their own. They also believe that they are more active and conscious in knowing latest trends in fashion and styles. Without social media their lives are incomplete now.

\section{References}

Abbas, J., Aman, J., Nurunnabi, M., and Bano, S. (2019). The impact of social media on learning behavior for sustainable education: evidence of students from selected universities in Pakistan. Sustainability, 11, 1683. DOI:10.3390/su11061683

Amedie, J. (2015). The impact of social media on society. Retrieved from http://scholarcommons.scu.edu/engl_176/2

Baker, E. (2019). The influences of social media: depression, anxiety, and self-conception. Retrieved from https://thekeep.eiu.edu/theses/4479

Bozkurt, A., Karadeniz, A., and Kocdar, S. (2017). Social networking sites as communication, interaction, and learning environments: perceptions and preferences of distance education students. Journal of Learning for Development, 4(3). 348-365. Retrieved from https://files.eric.ed.gov/fulltext/EJ1161784.pdf 
Dobrean, A. and Pasarelu, C. R. (2016). Impact of social media on social anxiety: a systematic review. DOI: $10.5772 / 65188$

Gay, L. R., Mills, G. E., and Airasian, P. W. (2015). Educational research: Competencies for analysis and application. Tenth edition. India: Pearson Publishers. Pages: 191-192

Gok, T. (2016). The effects of social networking sites on students' studying and habits. International Journal of Research in Education and Science, 2(1), 85-93.

Gorhe, M. (2019). Impact of Social Media on Academic Performance of Students. Retrieved from: https://www.researchgate.net/publication/332110622. DOI: 10.13140/RG.2.2.21427.27687

Hurst, B., Wallace, R. and Nixon, S. B. (2013). The impacts of social interaction on student learning. Reading Horizons: A Journal of Literacy and Learning Art, 52(4). Retrieved from https://scholarworks.wmich.edu/reading_horizons/vol52/iss4/5

Julian, H. (2017). How to define social media - an academic summary. Retrieved from http://julianhopkins.com/how-to-define-social-media-an-academic-summary/

Lad, H. (2017). The positive and negative impacts of social media on education, teenagers, business and society. International Journal of Innovative Research in Science, Engineering and Technology (IJIRSET), 6(10). DOI:10.15680/IJIRSET.2017.0610072

Lu, J. and Churchill, D. (2014). The effect of social interaction on learning engagement in a social networking environment. Interactive Learning Environment, 22(4), 401-417. DOI: 10.1080/10494820.2012.680966

Manning, J. (2014.) Social media, definition and classes of.In K. Harvey (Ed.), Encyclopedia of social media and politics (pp. 1158-1162). Thousand Oaks, CA: Sage.

Mensah, S. O. and Nizam, I. (2016). The impact of social media on students' academic performance - a case of Malaysia Tertiary Institution. International Journal of Education, Learning and Training, 1(1). DOI: 10.24924/ijelt/2016.11/v1.iss1/14.21. Retrieved from https://www.ftms.edu.my/journals/pdf/IJELT/Nov2016/14-21.pdf

O'Keeffe, G. S., Clarke-Pearson, K. and Council on Communication and Media (2011). Clinical report The impact of social media on children, adolescents and families. PEDIATRICS. DOI: 10.1542/peds.2011-0054

Okita, S. Y. (2016). Social interactions and learning. In: Seel, N. M. (Eds.) Encyclopedia of Sciences of Learning. Springer: Boston. DOI: https://doi.org/10.1007/978-1-4419-1428-6_1770

Owusu-Acheaw, M. and Larson, A. G. (2015). Use of social media and its impact on academic performance of tertiary institution students: a study of students of Koforidua Polytechnic, Ghana. Journal of Education and Practice, 6(6). Retrieved from https://files.eric.ed.gov/fulltext/EJ1083595.pdf

Pantic, I. (2014). Online social networking and mental health. Cyberpsychol Behav Soc Netw, 17(10), 652-657. DOI: 10.1089/cyber.2014.0070

Pojazon-Zazik, M. and Park, M. J. (2010). To tweet, or not to tweet: Gender differences and potential positive and negative health outcomes of adolescents' social internet use. American Journal of Men's Health, 4(1), 77-85. DOI: 10.1177/1557988309360819

Raut, V. and Patil, P. (2016). Use of social media in education: positive and negative impacts on students. International Journal on Recent and Innovative Trends in Computing and Communication (IJRITCC), 4(1), 281-285.

Siddiqui, S. and Singh, T. (2016). Social Media its impact with positive and negative aspects. International Journal of Computer Applications Technology and Research, 5(2), 71-75.

Sawyer, R. and Chen, G. M. (2012). The impact of social media on intercultural adaptation. Intercultural Communication Studies, 21(2), 151-169. Retrieved from: https://web.uri.edu/iaics/files/09RebeccaSawyerGuoMingChen.pdf

Strickland, A. (2014). Exploring the effects of social media use on mental health of young adults. 
Retrieved from https://stars.library.ucf.edu/cgi/viewcontent.cgi

Umar, T. I. and Idris, M. (2018). Influence of social media on psychosocial behavior and academic performance of secondary school students. Journal of Education and Entrepreneurship, 5(2), 36-46. https://doi.org/10.26762/jee.2018.40000013

Wolf, M., Sims, J., and Yang, H. (2018).Social Media? What Social Media? Retrieved from https://www.ukais.org/resources/Documents/ukais\%202018\%2oproceedings\%2opapers/pape r_4.pdf 